\title{
Taidehistoriasta toisaalle - rajapintoja ja uusia suuntia
}

\author{
Nina Kokkinen \& Ritkka Niemelä
}

doi.org/10.23995/tht.112138

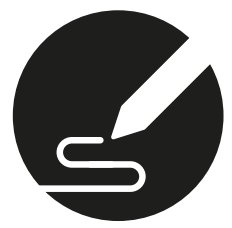

Kaikki muuttuu alati. Vaikka kyse ei aina olisikaan suurista liikkeistä, repivistä murroksista tai voimalla kuohuvista koskista, muutos on väistämätön. Hiljalleen virtaava vesi hioo lopulta pysyvyyttä uhkuvan kallion pintoja uusiin muotoihin.

Samoin käy tieteelle, taidehistorialle ja sen tekijöille. Ympäröivä maailma ja oma aikamme ohjaavat kohti uusia kysymyksiä ja katsomisen tapoja. Vaeltelut museoissa ja gallerioissa, meren rannoilla ja katujen varsilla virittävät ajatuksia, joita ruokimme lukemalla, kuuntelemalla ja keskustelemalla. Mitä taiteilijat ja teokset kertovat omasta ajastamme, tai menneestä? Askarruttavatko meitä samat kysymykset kuin ympäröivää yhteiskuntaa, antiikin ajattelijoita tai 1800-luvulla elänyttä kiinalaista kirjailijaa? Kiinnostavimmat pohdinnat ja vastaukset kutoutuvat joka tapauksessa esiin usein juuri silloin, kun niiden äärelle saavutaan eri suunnista - ja kenties myös totunnaisia tieteellisiä ja kulttuurisia rajanvetoja uhmaten.
Tahitin päätoimittajakauden vaihtuessa suuntamme katseemme taidehistoriasta toisaalle. Teemanumero on ensimmäinen osa Raja-trilogiasta, jolla haluamme herättää keskustelua kulttuurisista rajanvedoista ja niiden ylittämisen tai uudelleenasettumisen mahdollisuuksista. Trilogian ensimmäisessä teemanumerossa kysymisen ytimessä on taidehistoria tieteenalana. Olemme haastaneet kirjoittajat avaamaan niitä keskusteluja, jotka he kokevat ajankohtaisiksi taiteen ja sen tutkimuksen kannalta sekä pohtimaan, millaisten tutkimusongelmien ja aineistojen tarkastelussa rajojen haastaminen on tarpeellista. Teemanumerossa tunnustellaankin niitä monenkirjavia rajamaastoja, joita tutkijan on toisinaan osattava kartoittaa taiteesta kirjoittaessaan ja sitä ajatellessaan. Kirjoittajat liikkuvat kukin omalla tavallaan huokoisten rajojen tuntumassa.

Tieteenalojen ylittyessä syntyvä ymmärrys on tärkeä osa myös omaa identiteettiämme tutkijoina. Olemme itse kartoittaneet tutkimuksissamme muun muassa taidehistorian rajapintoja suhteessa uskontotieteeseen, esitystutkimuk- 
seen ja luonnontieteeseen. Koemme tärkeäksi suunnata myös Tahitia monitieteisille poluille ilman, että sen ydin - erikoistunut taidehistorian tuntemus - kuitenkaan katoaa. Toivomme, että päätoimittajakaudellamme Tahiti mahdollistaa laaja-alaisen keskustelun taidetta koskevista tieteellisistä ja yhteiskunnallisista kysymyksistä. Pyrkimyksemme on myös lisätä taiteen tutkimukseen liittyvää vuoropuhelua tutkijoiden, taiteilijoiden, museoammattilaisten, kuraattorien ja kriitikoiden kesken. Siltojen rakentaminen ja niiden väliin jäävien kuilujen tarkastelu johtaa parhaimmillaan uudenlaiseen ajatteluun ja voi ravistella konventiota hedelmällisin tavoin.

Yhteiskunnalliset keskustelut muokkaavat väistämättä käsityksiä siitä, mitä ja miten tulisi tutkia. Ne antavat myös nykyhetkessä suuntia sille, mihin taidehistorioitsija voi toisaalle tähytessään liikkua. Yksi viime vuosikymmenten tärkeimmistä pyrkimyksistä on ollut ongelmallisten esitystapojen tai marginalisoivien ja eriarvoistavien valta-asetelmien purkaminen. Kriittisyydestään huolimatta oman aikansa yhteiskunnallisesta aktivismista kasvaneet Uuden taidehistorian lähestymistavat säilyttivät taidehistorioitsija David Carrierin mukaan tarkastelun painopisteen länsimaisessa taiteessa. Pohtiessaan vuonna 2007 mahdollisuutta kirjoittaa maailman taiteen historiaa Carrier lähti liikkeelle Edward Saidin kysymyksistä: millä tavoin toisia kulttuureja representoidaan ja mitä toisella kulttuurilla lopulta tarkoitetaan? Tulisiko erillisen kulttuurin käsitteestä sittenkin luopua? ${ }^{1}$

Kysymykset ovat edelleen hyvin ajankohtaisia ja ne ovat näkyvästi läsnä myös taidehistorian uusia suuntia pohtivassa teemanumerossamme. Jälkikoloniaaliset tarkastelutavat ovat lisänneet tieteenalamme herkkyyttä huomioida sitä, miten toisista kulttuureista ja moninaisuudesta kirjoitetaan. Toiveet yhdenvertaisuuden toteutumisesta voivat kuitenkin johtaa myös eräänlaiseen

1 David Carrier, A World Art History and Its Objects (Pennsylvania State University Press, 2007), xxii-xxiv. värisokeuteen, kuten brittiläinen toimittaja Reni Eddo-Lodge toteaa paljon puhutussa teoksessaan Miksi en enää puhu valkoisille rasismista (2021). Tasa-arvoisuutta painottavan puheen ongelma piilee siinä, ettei se tee kyllin näkyväksi yhteiskunnan rakenteisiin - tai taidehistorian tutkimukseen - kietoutunutta eriarvoisuutta. ${ }^{2} \mathrm{Hie}-$ rarkkiset valta-asetelmat ovat konkretisoituneet esimerkiksi halussamme kuvata toisia kulttuureja autenttisesti, kuten Marie-Sofie Lundströmin artikkeli osoittaa. Tai siinä, mitä ja miten tutkitaan, tai kenelle tekijyys myönnetään, kuten Essi Lambergin katsausartikkeli taidehistorian ja kehitysmaatutkimuksen suhteesta tekee näkyväksi. Roni Grénin primitivismiin pureutuva kirja-arvio puolestaan nostaa esiin taidehistorian historian ja käsitteiden ongelmallisia arvoasetelmia.

Myös huoli ilmastonmuutoksesta ja luonnon hiipuvasta monimuotoisuudesta ovat viime vuosina sulautuneet merkittäväksi osaksi taidetta, taiteen tutkimusta ja näistä käytyjä keskusteluja. Se on muovannut uudenlaisia praktiikkoja, tutkimuskysymyksiä, teorioita, menetelmiä ja tekoja. Tässä numerossa näiden kysymysten äärelle on pysähtynyt Taru Elfving, jonka puheenvuorossa tunnustellaan kuraattorin roolia ympäristöhaasteiden ohjaamalla taiteen kentällä. Kirjoitus toimii jo eräänlaisena tienviittana kohti Raja-trilogian tekeillä olevaa toista teemanumeroa, Yhteenkietoutumia, joka julkaistaan syksyllä 2022. Siinä ruoditaan niitä tapoja, joilla taide haastaa ajattelun ihmiskeskeisyyttä tai käsitystä ihmisen ja ympäröivän todellisuuden erillisyydestä.

Tärkeän painopisteen Taidehistoriasta toisaalle -teemanumeroon muodostavat myös teostutkimuksen ja restauroinnin kysymykset. Taideteosten attribuoinnin ja kunnostuksen käytännöissä taidehistorioitsijan asiantuntemus lomittuu usein toisenlaiseen osaamiseen, esimerkiksi sismista (Gummerus, 2021). 
luonnontieteen tutkimusmenetelmien ja tekniikkojen hyödyntämiseen. Näihin rajapintoihin tarkentavat niin Anne-Maria Pennosen, Kirsi Hiltusen ja Hanne Tikkalan monialaista yhteistyötä teostutkimuksessa kuvaava tapaustutkimus kuin Emilia Laaksovirran artikkeli, jossa pohditaan erilaisten valintojen vaikutuksia restaurointiin. Minerva Keltanen avaa lektiossaan väitöstutkimustaan, joka käsittelee karnevalistista serenadi kissalle -aihetta ja muun muassa attribuoinnin haasteita. Esiin piirtyvät jälleen tekijyyden ja autenttisuuden kysymykset - nyt vain hieman toisin esitettyinä. Myös arkistoinnissa, kokoelmanhallinnassa ja konservoinnissa tehdään arvoihin perustuvia päätöksiä, jotka edellyttävät jatkuvaa kriittistä pohdintaa.

Väsymätöntä uudelleenarviointia kaipaavat edelleen myös taidehistorian lähestymistavat, kertomukset ja kaanonit. Yhden näkökulman näihin kysymyksiin tarjoaa Maunu Häyrysen ja Linda Leskisen artikkeli, joka paikantaa sokeita pisteitä taide- ja tekijäkeskeisessä arkkitehtuurintutkimuksessa. Altti Kuusamon artikkelissa taas arvioidaan kriittisesti anakronistisen otteen mahdollisuuksia ja ehdotetaan vaihtoehdoksi toisenlaisia ajallisuuden ymmärtämisen tapoja.

Miten siis taiteen historiaa tulisi kirjoittaa - tässä hetkessä, uusien haasteiden keskellä? Monet taiteesta ja sen historiasta kirjoittavat tutkijat ovat tottuneet julkaisemaan ajatuksiaan laajalla tekstilajien skaalalla vertaisarvioiduista artikkeleista taidekritiikkeihin ja näyttelykatalogeihin. Nykyisin tutkijoiden odotetaan yhä useammin myös osallistuvan yhteiskunnalliseen keskusteluun. Tekstilajien moninaisuus ja erilaiset odotukset asettavat kirjoittamiselle omat haasteensa. Tutkija-kriitikko Asta Kihlmanin puheenvuoro avaa taidekriitikon ja taiteen tutkijan sanallistamistapojen eroavaisuuksia ja yhtäläisyyksiä. Susanna Aaltosen, Marja-Leena Ikkalan, Hanna Kempin ja Juhana Lahden katsausartikkelissa taas valote- taan digiajan termityöskentelyä, joka muodostaa tärkeän pohjan omakielisen tutkimuksen tekemiselle. Kansainvälistymisen paineessa yksi taidehistorian tutkimuksen haasteista on ylläpitää edellytyksiä sille, että korkeatasoista tutkimusta voidaan tehdä myös suomen- ja ruotsinkielisenä.

Laadukkaan, omakielisen taidehistorian tutkimuksen julkaiseminen on yksi Tahitin keskeisistä tavoitteista. Lehden uudistunut ulkoasu takaa myös avoimen julkaisemisen periaatteita noudattavan lehden paremman saavutettavuuden. Tahitin ilmeen uudistamisesta on vastannut kuvataiteilija-graafikko Johanna Havimäki. Haluamme kiittää paitsi häntä myös Suomen Muinaismuistosäätiötä, joka on tukenut Tahitin saavutettavuuden ja omakielisyyden kehittämistä. Taidehistoriasta toisaalle -teemanumeron ja Raja-trilogian toteuttamisen on puolestaan mahdollistanut Suomen Kulttuurirahastolta saamamme tuki. Kiitos!

Toivotamme antoisia lukuhetkiä taidehistorian tutkimuksen ajankohtaisten kysymysten ja rajapintojen äärellä!

FT, TaM Nina Kokkinen työskentelee tutkijatohtorina Donner-instituutissa (Åbo Akademin säätiö). Hän on perehtynyt taiteen ja uskonnollisuuden välisiin kytköksiin, 1800-luvun lopun ja 1900-luvun alun taiteeseen sekä modernin ja sen jälkeisen taiteen esoteeriseen henkisyyteen.

FT Riikka Niemelä on nykytaiteen historian tutkija ja ma. yliopisto-opettaja Turun yliopiston taidehistorian oppiaineessa. 